\title{
THE AGE OF CLUSTERS AND ITS INFLUENCE ON THEIR ACTIVITY PREFERENCES
}

\author{
Eva JIRČÍKOVÁ, Drahomíra PAVELKOVÁ, Magdalena BIALIC-DAVENDRA, \\ Lubor HOMOLKA
}

Faculty of Management and Economics, Tomas Bata University in Zlín, nám. T. G. Masaryka 5555, 76001 Zlín, Czech Republic

Received 28 January 2013; accepted 01 June 2013

\begin{abstract}
The aim of this paper is to determine whether there exist age dependent differences in the orientation of clusters' activities. The literature depicts different approaches to the cluster evolution process, highlighting that clusters are subject to a life cycle that emphasizes different sets of activities in various stages of their development. These activities appear to follow a certain trajectory, whereby the successful completion of initial less-intensive activities stimulates a shift in focus to more demanding, long-term projects. The presented research verifies that clusters can pass through different stages of development, and examines in detail their preferences for jointly-undertaken activities. Research, conducted on a sample of clusters of different countries and ages, was carried out through the use of questionnaires and structured interviews with cluster managers. It is a sample of so-called organized clusters, which have their own internal structure and which are characterized by conscious development. The study identified common cluster activities in the following areas: networking, human resources, research and innovations, business cooperation and promotion, support activities, lobbying, etc. The preference of their implementation was also ascertained. In addition, the analyzed sample was divided into two categories according to cluster age, allowing for a comparison and differentiation of the level of implementation of joint activities between embryonic and established clusters. The evaluation of this research demonstrated that in the selected groups of activities, there was a statistically significant difference in terms of their level of implementation in clusters of various ages.
\end{abstract}

Keywords: cluster, cluster age, cluster initiative, cluster activity.

Reference to this paper should be made as follows: Jirčíková, E.; Pavelková, D.; Bialic-Davendra, M.; Homolka, L. 2013. The age of clusters and its influence on their activity preferences, Technological and Economic Development of Economy 19(4): 621-637.

JEL Classification: L14, L26, R11.

Corresponding author Eva Jirčíková

E-mail: jircikova@fame.utb.cz 


\section{Introduction}

Clusters are a modern way of cooperation for both profit and non-profit organizations. Successful clusters enhance the efficiency of individual companies and drive economic development in many countries. Clusters offer to the participating companies many specific benefits in the form of economies of scale and reduced costs, increased speed of transfer of information and technologies, and enhanced innovative potential. Additional potential benefits are the increased power and voice of smaller member companies and the stimulation of the government to invest in the specialized infrastructure, as well as the possibility of an effective interconnection and partnership. In the past two decades, clusters have become a subject for scholars in regional studies and for regional politicians. Industry or regional clusters are today recognized as an important instrument for promoting industrial development, innovation, competitiveness and growth. Although primarily driven by the efforts of private companies and individuals, clusters are influenced by various actors, including governments and other public institutions at both national and regional levels (Skokan 2009; Hajek et al. 2011; Molina-Morales, Expósito-Langa 2012).

Clusters exist worldwide, and each one is unique. Clusters have different characteristics, such as their own history, participants, relationships, strong and weak points, ambient conditions, etc. They can be identified by their different approaches and methods (see e.g. Zizka 2004, 2008, 2012) and can be characterized as 1) "natural clusters" - according to the definition of Porter (1990) or 2) institutionalized (organized) clusters.

Through their activities, organized clusters meet pre-defined objectives. Different types of activities can be implemented within a cluster, which can contribute to an increase in efficiency of individual companies and/or regional development (Lechner, Leyronas 2012). This study examines the orientation of the activities and the degree of their implementation in initial and subsequent stages of cluster evolution. The assumption of different stages of cluster development and their governance is based on the life cycle model described in the literature (Andersson et al. 2004; Bergman 2008; Van Klink, De Langen 2001; Chandrapala et al. 2010, etc.), where the idea of life cycle implies some sort of ageing process. Martin and Sunley (2011) question the application of the idea of the life cycle in the evolving clusters. They argue that during the development of the cluster, new companies enter the network while others may exit; and, the characteristics of the companies creating the cluster (their products, technologies, routines, business models, etc.) may change over time. The life cycle model is replaced by an adaptive cycle inspired by ecological fundamentals.

Although views on the life cycle model and the adaptive cycle model are derived from different bases, both of them assume the existence of phases which differs by the characteristics of the cluster development. That clusters can pass through different stages of development is verified by the following study, which examines in detail the preferences of jointly-undertaken activities by the members of organized clusters. Based on the evaluation of data obtained from extensive empirical research and using selected statistical methods, the hypothesis that the age of the cluster and its maturity has an influence on the choice and preferences of cluster activities is verified. The research results confirm that the age of the cluster in accordance with the existence of different phases of cluster development has an effect on the orientation of the activities and preferences of cluster management in an organized (institutionalized) cluster. The statistically 
significant influence of the age of the clusters on the preference of activities by the established clusters in comparison to the embryonic clusters is reflected in activities implemented in the areas of human resources, some promotional activities, benchmarking, and lobbying.

This study identified the activities that are the most preferred among cluster activities, including networking, activities focused on joint research and development, and activities oriented to human resource development. These activities, according to the conducted research, represent the greatest source of competitive advantage for entities involved in cluster activities. These conclusions are derived from the statistical evaluation of the frequency of activities presently undertaken and those that are planned to be implemented by the cluster in the future. The findings, obtained through the study of clusters in both developed and emerging economies, can be used in the planning and implementation of cluster policies, economies and management practices of individual clusters, which have the form of institutionalized (organized) clusters.

\section{Theoretical background}

\subsection{Clusters, cluster initiatives and cluster activities}

The most well-known definition is Porter's (1990), in which clusters are being depicted as "geographic concentrations of interconnected companies, specialized suppliers, service providers, firms in related industries, and associated institutions (for example, universities, standards agencies, and trade associations) in particular fields that compete but also cooperate". It is also common that the formation of a cluster and the support of its development is connected with the so-called cluster initiative, which, according to the Cluster Initiative Greenbook (Sölvell et al. 2003), is defined as an organized effort focused on the increase of growth and competitiveness of a cluster in a region with the participation of cluster companies, government and/or research community.

As a result of support for cluster development, so-called organized clusters have developed in different countries. These, unlike natural clusters (defined by Porter), have organizational structure, vision and goals, management, and often legal form. Cluster governance carries out planned activities that support the development of their members - companies, research or educational institutions or other subjects.

According to Pavelková et al. (2009), common cluster activities are those jointly implemented by a group of cluster members or such activities (services) which are organized, e.g. by the cluster management (cluster organization) and provided to the members. Common cluster activities should support cluster strategy and should always be accomplished in connection with cluster vision and goals, and in regards to established priorities.

\subsection{Age of clusters and cluster evolving process}

A significant part of the literature focusing on the process of cluster evolution talks indirectly about the age of clusters - in the context of their life cycles.

Markets and firms (even products and technologies) go through development, growth and decline processes. The literature includes Klepper's (1996) industry life cycle model (see also Audretsch, Feldman 1996; Klepper 1997) and Utterback and Abernathy's (1975) technology 
life cycle model (see also Dalum et al. 2005). This also applies to clusters, which evolve over time, and different phases of their development can be identified. Various cluster activities can be associated with and implemented in different phases in the cycle.

Menzel and Fornahl (2009) note that "geographical cluster as such is only a theoretical concept that describes a particular constellation of different elements (e.g. companies, organizations, and networks) and processes (e.g. interaction and monitoring)", and therefore, "the movement of the cluster through the life cycle is not performed by the cluster, which is only a concept, but is the result of the activities and the evolution of its elements".

According to Pavelková et al. (2009), cluster activities usually follow a certain path starting from creating a platform for mutual cooperation of firms (networking), followed by common projects realized in sales, human resources, production and marketing areas, and projects in the area of $\mathrm{R} \& \mathrm{D}$. Cluster actors implement common activities in various areas both with short-term and long-term perspectives. In the literature can be found different perspectives on the life cycle of clusters with defined various stages of development and their characteristics. The focus on a cluster's evolutionary growth, however, is often contrasted with its disregard (Lorenzen 2005; Boschma, Frenken 2006).

The literature provides several views on distinguishing the stages of the life cycle, with scholars identifying different numbers of phases of cluster development and providing them with different names.

The first phase of a cluster's life cycle is an early stage of growth where the actors start to realize common opportunities and begin to cooperate. The cluster begins to exist and from this moment is inseparably related to innovations, inventions and internal investments. Major investments are important, and that is why every supporting policy in this early stage is critical. Innovators create new ideas, markets and processes. This stage means investing in the cluster, in its critical mass, and stimulating the awareness of companies.

In connection with the activities of the cluster, an oft-mentioned jargon is the "low hanging fruits”. This expression according to Pavelková and Jirčíková (2008) concerns fairly easy activities implemented in the early stages of development of the cluster. These activities do not require special resources, yet provide quick wins. The intention of their implementation is to demonstrate to participants of the organized cluster how valuable initial joint activities can be. Their successful completion develops trust among the cluster members, which is necessary for the implementation of sophisticated strategic activities. Identifying projects that may lead to initial successes also helps unify the steering (management) group. Following the completion of the first less-intensive activities, the cluster's focus shifts towards the long-term and substantive projects. In this phase, an update of the initial strategic decisions can often also be observed. The second phase is connected with further growth and begins when the market for a cluster's products is sufficiently developed. More and more firms appear (e.g. competitors, spin-offs), new actors enter the cluster and new linkages among actors develop. Relations among partners evolve and competitive pressure increases. Clusters enter into an international competition process (superior internal dynamics and attraction of outside resources - circulation of ideas, skills and resources - are being observed). The presence of a mix of advantageous diamond factors (Porter 1990) is needed in this stage. 
Further phases are characterized by stability or difficulties in further growth. Relations are developed inside and outside of the cluster. Stage processes and products become standardized. Inside the cluster develops an increase of competitive pressure. Gradually, attenuation may occur, products and services of the cluster are replaced by cheaper substitutes, or the possibility arises to innovate and re-start the cycle again. The cluster closes in its own environment, which previously constituted its strength, e.g. a qualified work force, unique knowledge, or strong linkages with other entities. It might fall into the trap of rigid specialization. The cluster can experience either a lock-in effect (Grabher 1993) used the metaphor of "the weakness of strong ties" to describe this effect (see also Hassink 2005), losing the ability to adjust to a changing environment, or a renaissance: entering new growth phases by integrating and applying new technologies and knowledge (Bergman 2008; Górzyński 2006; Martin, Sunley 2006; Menzel, Fornahl 2009; Staszewska 2009; Blahova, Knapkova 2011). Sölvell (2009) states that clusters, like every social system, go through birth, growth, decline and death.

The paths through which clusters go throughout their life cycle are not identical, and their evolution may vary (see also Saxenian 1994; Tel Wal, Boschma 2011). The literature depicts different perspectives on a cluster life cycle (see also works of Pouder, St. John 1996; Tichy 1998; Swann 1998; Brenner 2004). For example, Wolter (2003), while speaking about the life cycle for clusters (seeing them in a more generic sense, encompassing all forms of regional concentration of economic activity) develops a life cycle theory of agglomerations with set-up, growth, change and adaptation stages of development.

Van Klink and De Langen (2001) describe stages of a cluster's development within which certain related characteristics such as character of the value chain, strategic relations, cluster dynamics, co-operative domain, determinant for success and government's role in enhancing clustering can be distinguished. Special focus will be placed on the co-operative domain and the type of activities implemented within the life cycle phases (Halbert 2012).

Maskell and Kebir (2005) describe cluster-life cycle phases using three-stage development: existence, extension and exhaustion. Bergman (2008), in turn, similarly lists phases of existence, expansion, exhaustion and extinction, but also notes that not all clusters experience the life cycle in full. Following Bergman's (2008) view, Sonderegger and Täube (2010) illustrate the process of a cluster's life cycle with five stages: pre-cluster foundations, emergence, exploratory growth, exploitative growth and exhaustion. Malakauskaite and Navickas $(2010,2011)$ while talking about the linkages between level of clusterization, competitive advantage and cluster life cycle, distinguish several phases of a cluster life cycle, such as establishment, development including slow growth (development) of a cluster and fast growth (development) of a cluster, maturity, maturity transforming into the decline of a cluster, decline and transformation.

Martin and Sunley (2011) accept the idea of the adaptive cycle model of cluster evolution. They comment that the boundary between a complex adaptive system (which the cluster is) and its environment is neither fixed nor easy to identify, and the system is subjected to constant exchange with its environment. Cluster evolution has to be seen in the context of its co-evolution with the (global) industry of which it is itself a part. Martin and Sunley question the possibility of applying the life cycle model concept to clusters and offer an adaptive model inspired by ecological fundamentals. The phases of a cluster's full adaptive cycle can be recognized: emergence, growth, maturation, decline and eventual replacement by a new 
cluster. The authors highlight the fact that all clusters pass through all phases. The adaptive cycle model represents a heuristic meta-model of a continuous dynamic process, but it does not claim to describe a rigid, predetermined path or trajectory.

From this review of relevant literature on the development of clusters, it is evident that economists distinguish different stages of cluster development and also characterize them in various ways. It is also clear that clusters are complex organisms made up of different elements in different stages of development and with different abilities to adapt to changing environmental conditions (macro conditions, conditions of the industry itself, etc.). The opportunity to identify at least two basic stages of development of mutual relations between the elements of this organism can be seen - i) the stage of emerging, young clusters (emergent, embryonic clusters) with elements of creation and consolidation of mutual relations and starting the elements of cluster governance, and ii), the stage of clusters evolving their activity with stable cluster governance, where the cluster development directions are already defined and specifically developed using selected joint activities.

\section{Research objectives and hypothesis}

The presented research results deals with clusters and their activities. The research objective is to analyze what kinds of joint activities clusters prefer and whether the preferences of activities vary depending on the age of the clusters. Within this research, individual activities in terms of their current or planned implementation will be statistically evaluated and the null hypothesis will be tested: No relationship exists between the implementation of activities and the age of the cluster.

\section{Research methods}

\subsection{Definition of a cluster used in this study}

For the purpose of this study, the definition of "a cluster" has been narrowed. The main goal of this project is not an examination of natural (Porter's) cluster functioning. Therefore, it focuses primarily on those clusters that can be classified as having "conscious development", i.e. such clusters that are consciously managed and organized (institutionalized).

The reason for the narrower definition of "cluster" is stems from the fact that it is possible to organize, manage, support and develop cluster, to facilitate mutual cooperation among competitors and ultimately lead to benefits both for the cluster members and for the region in which the cluster operates.

\subsection{Methods of data acquisition}

The Faculty of Management and Economics at the Tomas Bata University in Zlín (Czech Republic), in cooperation with a number of other organizations in the Czech Republic and abroad, actively engaged in a project that studied the measuring and management of cluster performance. The financial support for the project was provided by the Grant Agency of the 
Czech Republic (project “Clusters Performance Measurement and Management”). During the work on this project, which lasted from 2006 to 2008, extensive research on clusters and cluster initiatives was carried out.

Currently, the research is being continued within the support of the project entitled "The Development and Evaluation of the Performance of Cluster Policies, of Clusters and their Members with the Usage of the Principles of Benchmarking", supported by the Internal Grant Agency of Tomas Bata University in Zlín, and the project "Clusters Performance Measurement and Management" supported by the International Visegrad Fund. Their basic goal is the expansion of scientific knowledge and the creation of a knowledge database for the study of the performance of clusters, cluster policies and cluster members.

Two methods of investigation were used within this project: a questionnaire and structured interviews. Questionnaires were sent to the managers (steering groups) of 640 clusters worldwide. The research was based on the results of 169 completed questionnaires. In one-third of the clusters (56), this investigation was supported by a structured interview with the managers of the cluster. The goal of the interviews was to gather detailed information regarding the process of cluster development, and also to receive feedback from cluster managers: their views and experiences. The aim of the survey was to obtain information about the tools, methods and good practices used for successful cluster development. The questionnaire was divided into four thematic areas:

- basic characteristics of the cluster;

- cluster activities (services and joint actions);

- cluster management and financing;

- cluster performance.

Cluster activities (the subject of the study) were identified through research and communication with cluster managers and experts in clusters and cluster initiatives. On the basis of the research conducted (Sölvell et al. 2003; The Cluster Initiative Greenbook 2003; Innovating Regions in Europe - IRE subgroup on Regional clustering and networking as innovation drivers: Cluster Management - Learning module 5; Clusters Linked... 2006; Pavelková et al. 2009), cluster activities have been divided into the following areas:

- Networking;

- Human resources;

- Research and innovations;

- Business cooperation and promotion;

- Financing investment projects;

- Lobbying;

- Other activities.

\subsection{Characteristics of the research sample}

The cluster questionnaire received 169 responses: 66 in 2007, 93 in 2010, and 10 in 2011. The respondents represented clusters from 23 countries worldwide: Australia, Austria, Belgium, Canada, Croatia, the Czech Republic, Denmark, Estonia, Finland, Germany, Great Britain, 
Hungary, Iceland, India, Italy, New Zealand, Norway, the Philippines, Poland, Slovenia, the Slovak Republic, Spain, and the USA. The vast majority of the respondents were from Europe (150; 89\%).

For this study, clusters were divided into two categories depending on their age - Embryonic clusters (EMB) and Established clusters (EST). The criterion for inclusion in these two groups was the age of the cluster at the time of the study. Embryonic clusters, represented in the research by $135(80 \%)$ clusters, were those, which were created less than five years ago from the date of the study. The share of Established clusters in the sample was $20 \%$ (34 clusters). The boundary of five years has been tested as a boundary marking a significant change in the number of activities implemented by clusters. Embryonic clusters are emerging clusters, defining their goals and starting their joint activities. Established clusters are already mature.

\subsection{Methods of data processing and evaluation}

Within the study, different statistical characteristics were used - relative frequency, mode, and mutability. In order to test the dependence between the implementation of activities and the age of the cluster, a contingency table was created. Due to the small sample, the dependence was set both directly and by using the simplified Monte Carlo simulations (5000 replications). As Hope (1968) showed, at a set to 5\% and a sample size larger than 160, this procedure corresponds to the most powerful test based on $\chi^{2}$ distribution. The intensity of this dependence was found by Yule $\phi$ coefficient, which measures the product-moment correlation of two binary variables.

\section{Research results}

Within this study, the preference for the implementation of individual cluster activities was investigated. Managers of clusters reported in the questionnaire that the listed activities are either being implemented by their clusters (code " 1 ") or if not implemented, whether they are planning to implement them in the future (code " 2 "), or neither implemented nor planned implementation (code " 3 "). Looking at the results of the popularity of particular activities (Table 1), it is evident that among the most common clusters activities are those in the area of networking (information support, common workshops, meetings, arranging contacts among cluster members and with vendors or customers). These are already being implemented or will be implemented by nearly all respondents.

Next in order of preference are: activities in the area of research and innovations (joint $\mathrm{R} \& \mathrm{D}$, innovations of products and processes, cooperation with research institutions) and activities in the area of human resources (organizations of joint seminars and conferences, training of employees, cooperation with educational institutions). These activities are implemented almost by $2 / 3$ of clusters and are being planned by more than $20 \%$ of clusters.

Among the relatively popular are promotion activities (research of trends and markets, joint participation in trade fairs, common catalogue of products and services, joint logo, trade name, joint advertisement). More than half of the clusters have already implemented them; another quarter is planning to do so in the future. 
Table 1. Evaluation of implementation of activities (regardless of cluster age)

\begin{tabular}{lccc}
\hline The order of activities & $\begin{array}{c}\text { "1" } \\
\text { clusters currently } \\
\text { offer the activity (\%) }\end{array}$ & $\begin{array}{c}\text { "2" } \\
\text { clusters currently } \\
\text { do not offer the activity } \\
\text { but plan on doing so } \\
\text { in a few years (\%) }\end{array}$ & $\begin{array}{c}\text { "1+2" } \\
\text { clusters currently offer } \\
\text { the activity or plan } \\
\text { on doing so in } \\
\text { a few years (\%) }\end{array}$ \\
\hline Networking & 76.8 & 15.0 & 91.8 \\
\hline Research and innovations & 61.0 & 22.1 & 83.1 \\
\hline Human resources & 60.7 & 23.9 & 84.6 \\
\hline Promotion & 54.6 & 23.8 & 78.4 \\
\hline Lobbying & 49.8 & 21.1 & 70.9 \\
\hline Support activities & 40.3 & 21.9 & 62.2 \\
\hline Other activities & 18.4 & 21.4 & 39.8 \\
\hline Business cooperation & 17.6 & 22.9 & 40.5 \\
\hline
\end{tabular}

Lobbying activities (in favour of infrastructure, more favourable legal regulations, and lobbying for subsidies) are implemented by nearly half of the clusters in the survey and a further one-fifth is going to implement them.

Support activities (such as help in projects, benchmarking and different support services) in average are implemented by $40 \%$ of clusters and more than $20 \%$ are planning to do so. The most widespread support activity is help in preparation and/or management of projects (64\% of clusters offer it). Support services in the form of banking services, insurance, legal, accounting and tax consultancy, etc. are not commonly provided. Benchmarking is quite popular, as $32 \%$ of the clusters already use it.

Business cooperation in the form of logistic management, joint purchase or shared production, is a quite rare activity. These activities are conducted only by a minor number of clusters (approx. $18 \%$ of respondents). However, more than $20 \%$ of clusters plan to implement them in the future.

Similar results are observed in the group called "other activities", which include joint investments in infrastructure, help in obtaining financial resources, support of spin-offs, incubator services and the electronic marketplace. These activities are not a priority for clusters.

The popularity of the implementation of activities has been evaluated for the entire sample of the surveyed clusters, irrespective of their age. The sample contained both clusters in the embryonic stage and established clusters. In further research, the sample is divided according to the age of clusters and separately evaluates the implementation of individual activities (Table 2). From the evaluation, it is evident that established clusters implement almost all activities to a greater extent.

An interesting is that the percentage of clusters implementing and planning to implement the activity (the sum of answers " 1 " and " 2 ") in the embryonic and established clusters is similar in regard to the more popular activities (with the exception of the area of business cooperation). Nevertheless, embryonic clusters characterize a larger proportion of those which only plan to implement the activity. Consequently, it follows that the general popularity of the activities is the same, but cluster age increases the utilization of activities. 
Table 2. Evaluation of implementation of activities depending on the age of clusters

\begin{tabular}{|c|c|c|c|c|c|c|c|c|}
\hline & \multicolumn{2}{|c|}{$\begin{array}{c}\% \text { of clusters } \\
\text { with an } \\
\text { answer "1" }\end{array}$} & \multicolumn{2}{|c|}{$\begin{array}{c}\% \text { of clusters } \\
\text { with an } \\
\text { answer " } 1+2 \text { " }\end{array}$} & \multicolumn{2}{|c|}{ Mutability } & \multicolumn{2}{|c|}{ Modus } \\
\hline & EMB & EST & EMB & EST & EMB & EST & EMB & EST \\
\hline Networking: & 75 & 85 & 92 & 92 & 0.407 & 0.265 & & \\
\hline Information support & 75 & 88 & 93 & 97 & 0.405 & 0.225 & 1 & 1 \\
\hline Common workshops, meetings & 87 & 88 & 96 & 94 & 0.241 & 0.221 & 1 & 1 \\
\hline Arranging contacts among cluster members & 90 & 97 & 99 & 97 & 0.191 & 0.059 & 1 & 1 \\
\hline Arranging contacts with vendors or customers & 47 & 68 & 80 & 79 & 0.635 & 0.501 & 1 & 1 \\
\hline Human resources: & 56 & 80 & 85 & 85 & 0.584 & 0.336 & & \\
\hline Organization of joint seminars and conferences & 64 & 85 & 89 & 91 & 0.524 & 0.277 & 1 & 1 \\
\hline Training of employees & 35 & 65 & 75 & 71 & 0.659 & 0.506 & 2 & 1 \\
\hline Cooperation with educational institution & 69 & 91 & 90 & 94 & 0.478 & 0.169 & 1 & 1 \\
\hline Research and innovations: & 60 & 67 & 85 & 75 & 0.558 & 0.489 & & \\
\hline Joint research and development & 56 & 71 & 81 & 74 & 0.594 & 0.444 & 1 & 1 \\
\hline Cooperation with research institutions & 77 & 79 & 92 & 88 & 0.388 & 0.358 & 1 & 1 \\
\hline Innovations of products and processes & 47 & 50 & 83 & 62 & 0.625 & 0.608 & 1 & 1 \\
\hline Business cooperation: & 17 & 19 & 44 & 28 & 0.584 & 0.445 & & \\
\hline Joint purchasing & 26 & 27 & 55 & 33 & 0.651 & 0.492 & 3 & 3 \\
\hline Shared production & 15 & 12 & 39 & 24 & 0.554 & 0.409 & 3 & 3 \\
\hline Logistics management & 10 & 18 & 36 & 27 & 0.520 & 0.443 & 3 & 3 \\
\hline Promotion: & 52 & 63 & 79 & 77 & 0.612 & 0.529 & & \\
\hline Marketing research on trends and markets & 47 & 58 & 82 & 70 & 0.629 & 0.580 & 1 & 1 \\
\hline Joint participation in trade fairs & 56 & 85 & 77 & 94 & 0.591 & 0.269 & 1 & 1 \\
\hline Catalogue of products and services & 41 & 65 & 74 & 82 & 0.660 & 0.535 & 1 & 1 \\
\hline Joint logo, trade name & 66 & 56 & 81 & 66 & 0.513 & 0.575 & 1 & 1 \\
\hline Joint advertisement & 52 & 52 & 80 & 71 & 0.617 & 0.632 & 1 & 1 \\
\hline Support activities: & 38 & 48 & 63 & 61 & 0.656 & 0.601 & & \\
\hline Help in preparation and management of projects & 64 & 67 & 83 & 73 & 0.533 & 0.492 & 1 & 1 \\
\hline Benchmarking & 27 & 52 & 60 & 64 & 0.664 & 0.606 & 3 & 1 \\
\hline Support service & 23 & 27 & 44 & 45 & 0.595 & 0.614 & 3 & 3 \\
\hline Lobbying: & 45 & 68 & 70 & 75 & 0.645 & 0.476 & & \\
\hline in favour of infrastructure & 43 & 67 & 69 & 70 & 0.656 & 0.477 & 1 & 1 \\
\hline for more favourable legal regulations & 41 & 63 & 67 & 72 & 0.660 & 0.538 & 1 & 1 \\
\hline for subsidies & 52 & 75 & 74 & 84 & 0.619 & 0.417 & 1 & 1 \\
\hline Other: & 17 & 23 & 40 & 38 & 0.561 & 0.543 & & \\
\hline Joint investments in infrastructure & 19 & 26 & 46 & 38 & 0.603 & 0.551 & 3 & 3 \\
\hline $\begin{array}{l}\text { Obtaining financial resources } \\
\text { (banks, venture capital, etc.) }\end{array}$ & 23 & 21 & 45 & 41 & 0.600 & 0.586 & 3 & 3 \\
\hline Support of spin-off creation & 17 & 29 & 43 & 50 & 0.581 & 0.640 & 3 & 3 \\
\hline Incubator services & 13 & 24 & 27 & 35 & 0.439 & 0.528 & 3 & 3 \\
\hline Electronic marketplace & 13 & 13 & 40 & 23 & 0.557 & 0.398 & 3 & 3 \\
\hline
\end{tabular}

* Code 1 -Clusters currently offer the activity to their members; Code 2 - Clusters currently do not offer the activity, but plan to do so in a few years; Code 3 - Clusters neither offer nor plan the activity

** Embryonic clusters (EMB), Established clusters (EST) 
The study also shows that the established clusters are less likely to plan to implement activities in the area of business cooperation, not seeing the need to do so. Embryonic clusters are more active in planning such future activities. The results also show that shared production and logistics management are the least common activities among clusters. Conversely, the most frequent activities among both embryonic and established clusters are various forms of networking.

Table 2 presents the results of an examination of the conformity of the respondents' answers in the form of mutability (if mutability is equal to 0 , the group is homogenous - all respondents answered the question alike; if the mutability equals 1, answers were different), while modus determines which of the answers given by respondents appeared most often in regards to individual activities.

The established clusters show a higher degree of consensus in answers concerning the implementation of individual activities, demonstrating the greater expediency of individual activities for joint implementation within a cluster (either a positive or negative attitude towards individual activities). A great degree of consensus also exists over networking activities. Compliance is quite high also in cooperation with educational institutions, joint participation in trade fairs and the organization of joint seminars and conferences. The implementation of activities aimed at networking, human resource management, $\mathrm{R} \& \mathrm{D}$, promotion, lobbying and help in the preparation and management of projects were the most frequent answers given by cluster managers. In regards to the activities focused on business cooperation, support services and activities in the group labelled "other", the answer that clusters neither offer nor plan the activity appeared most often. A significant difference between embryonic and established clusters exists in regards to benchmarking, which is significantly more popular with established clusters. This shows a greater awareness by the established clusters of the possibilities associated with cooperation in this area, and also overcoming the initial mistrust of cluster members who are often afraid to share data and information.

Figure 1 graphically demonstrates a comparison of the implementation of individual activities by embryonic and established clusters.

In order to demonstrate statistical dependence in the implementation of the activities determined by the age of the cluster, individual activities have been evaluated with the usage of a $2 \times 2$ contingency table. A statistically significant change in the structure of answers on the usual significance level $\alpha=5 \%$ has been demonstrated in the activities listed in Table 3 . The null hypothesis that there is no relationship between the implementation of activities and the age of the cluster (the assignment of clusters among established or embryonic clusters) was tested. In this case, the p-value was calculated according to the asymptotic distribution. Due to the fact that it is not a continuous variable, it was necessary to perform a Yates correction in order to determine this value. The second approach to calculate the p-value was re-sampling. Discontinuous function was transferred to continuous; several thousand variants of the original combination table were created with the usage of the simplified Monte Carlo method - a 5000 replication was performed with the statistical software R (R Development Core Team 2011).

The table also depicts dependence power measured by Yule $\phi$ coefficient. 


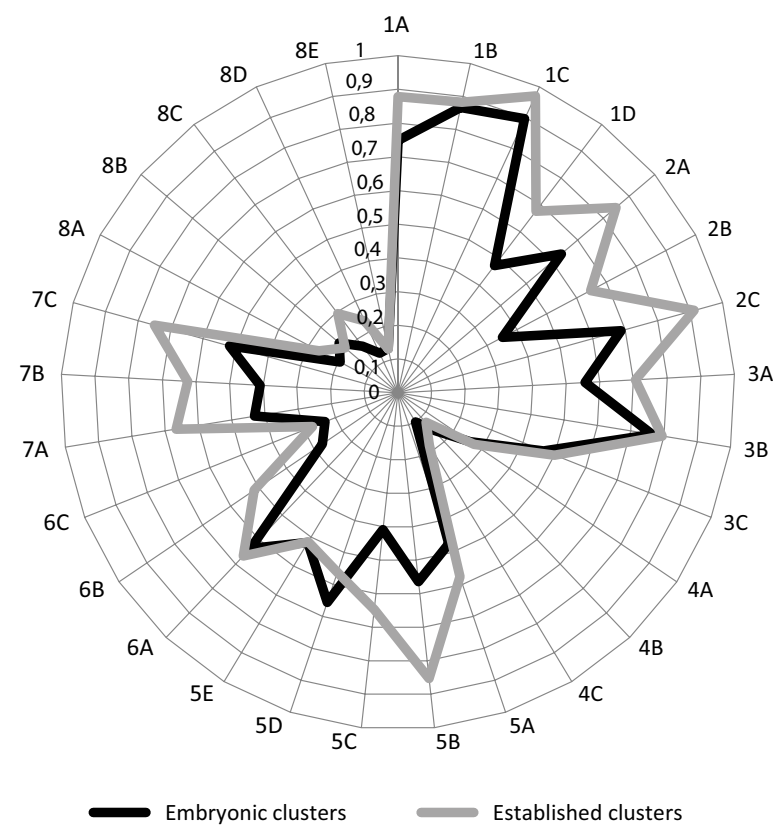

Legend:

1A Information support

1B Common workshops, meetings

1C Arranging contacts among cluster members

1D Arranging contacts with vendors or customers

2A Organization of joint seminars and conferences

2B Training of employees

2C Cooperation with educational institutions

3A Joint research and development

3B Cooperation with research institutions

3C Innovations of products and processes

4A Joint purchasing

4B Shared production

4C Logistics management

5A Marketing research

5B Joint participation in trade fairs

5C Catalogue of products/services

5D Joint logo, trade name

$5 \mathrm{E}$ Joint advertisement
6A Help in preparation and management of projects

6B Benchmarking

6C Support services

7A Lobbying in favour of infrastructure

7B Lobbying for legal regulations

7C Lobbying for subsidies

$8 \mathrm{~A}$ Joint investments in infrastructure

8B Obtaining financial resources

8C Support of spin-off creation

8D Incubator services

$8 \mathrm{E}$ Electronic marketplace

Fig. 1. A comparison of activities implemented by embryonic and established clusters

A pronounced preference of activities by the established clusters in comparison to embryonic clusters is reflected in activities in the area of human resources, and some activities in the area of promotion, benchmarking, and lobbying. 
Table 3. Activities with a statistically-significant change in the structure of responses according to the age of clusters

\begin{tabular}{|c|c|c|c|}
\hline & $\begin{array}{c}\text { X-squared } \\
\text { (Yates correction) }\end{array}$ & $\begin{array}{c}\text { p-value } \\
\text { (Yates correction) }\end{array}$ & $\begin{array}{l}\text { Yates phi } \\
\text { (Yule } \phi\end{array}$ \\
\hline & (Monte Carlo Method) & (Monte Carlo Method) & coefficient) \\
\hline \multirow{2}{*}{$\begin{array}{l}\text { Organization of joint } \\
\text { seminars and conferences }\end{array}$} & 4.5187 & 0.03353 & \multirow{2}{*}{0.181711} \\
\hline & 5.4481 & 0.0236 & \\
\hline \multirow{2}{*}{ Training of employees } & 8.4376 & 0.003675 & \multirow{2}{*}{0.241991} \\
\hline & 9.6286 & 0.002799 & \\
\hline \multirow{2}{*}{$\begin{array}{l}\text { Cooperation with } \\
\text { educational institutions }\end{array}$} & 5.9117 & 0.003675 & \multirow{2}{*}{0.204313} \\
\hline & 7.013 & 0.008198 & \\
\hline \multirow{2}{*}{$\begin{array}{l}\text { Joint participation } \\
\text { in trade fairs }\end{array}$} & 8.4376 & 0.003675 & \multirow{2}{*}{0.240117} \\
\hline & 9.6286 & 0.002799 & \\
\hline \multirow{2}{*}{$\begin{array}{l}\text { Catalogue of products } \\
\text { and services }\end{array}$} & 5.2465 & 0.003675 & \multirow{2}{*}{0.192760} \\
\hline & 6.168 & 0.0198 & \\
\hline \multirow{2}{*}{ Benchmarking } & 6.0931 & 0.01357 & \multirow{2}{*}{0.210352} \\
\hline & 7.1682 & 0.0118 & \\
\hline \multirow{2}{*}{$\begin{array}{l}\text { Lobbying in favour } \\
\text { of infrastructure }\end{array}$} & 4.9619 & 0.02591 & \multirow{2}{*}{0.189756} \\
\hline & 5.8692 & 0.0212 & \\
\hline \multirow{2}{*}{$\begin{array}{l}\text { Lobbying for more } \\
\text { favourable legal regulations }\end{array}$} & 4.0161 & 0.04507 & \multirow{2}{*}{0.171947} \\
\hline & 4.8488 & 0.03179 & \\
\hline \multirow{2}{*}{ Lobbying for subsidies } & 4.7054 & 0.03007 & \multirow{2}{*}{0.184326} \\
\hline & 5.6061 & 0.02559 & \\
\hline
\end{tabular}

\section{Discussions}

A study of a sample of clusters from various countries and different age levels identified certain activities on which clusters are primarily oriented. The most often implemented are those aimed at networking; also popular are activities in the area of human resources, $\mathrm{R} \& \mathrm{D}$, promotion and lobbying. These are the areas in which the majority of clusters in the sample already implement (or plan to implement) common activities (networking activities - almost all clusters).

As a result of the examination of the implementation of activities by clusters, differentiated by embryonic and established clusters, it can be stated that with few exceptions the established clusters implemented a greater range of activities; though, it is logical to assume that they have more time to develop more activities for their members. Established clusters exhibit a greater reluctance to implement or if necessary to plan activities focused on business cooperation, especially in the area of shared production and logistics management, which are among the least implemented activities. Significantly more established clusters are dedicated to benchmarking in comparison to the embryonic clusters.

This study attempted to identify the influence of life cycle on cluster activity. On the basis of the research results, the null hypothesis that there is no relationship between the implementation of activities and the age of clusters at the level of probability of $5 \%$ is rejected. 
Research and statistical evaluation of data confirmed that there exist certain activities in which organized clusters are involved, which are preferred by clusters at specific ages. The given results contribute to the experts' opinions that clusters, in terms of the focus on activities, pass through an evolution process.

A weakness of this study is that only one-third of the surveyed cluster managers were subjected to structured interviews. In regard to these clusters, it is unlikely that the questions the cluster managers were asked were not clear, as an opportunity to personally explain the potential misinterpretations were afforded. However, this was not possible for all respondents. Another weakness is the limiting of the study to only two groups of clusters - identified as embryonic and established. A more detailed division of the established clusters into further, finer subgroups according to their age was not possible due to the small sample size (34 clusters), which could not be further diluted. Distribution into the given groups was tested on the basis of the significance of changes in the number and preference of implemented activities.

Despite the weaknesses, this expensive and time consuming study yielded valuable results. It is now empirically verified that there is a difference in the preference of the activities undertaken by clusters depending on their age.

The research results showing these preferences point to the experience gained by the individual clusters and their management, which they use to better target cluster activities and financial and institutional support in order to increase performance of cluster members and thus influence regional development.

\section{Conclusion}

The results of a study aimed at the activities of organized clusters were presented in three levels: i) interest in the implementation of cluster activities, which were formulated on the basis of scholarly research and interviews with selected cluster managers prior to the study; ii) a division of the sample into embryonic and established clusters according to predefined criteria and an examination of the difference in preferences in implemented or planned activities (supplemented by monitoring the degree of conformity in the responses and the most frequent answers); and iii) testing the null hypothesis regarding the absence of dependencies between the implementation of activities and the age of a cluster at a given level of probability.

This study produced interesting results in terms of verification of the attractiveness of individual activities for their implementation by organized clusters, preferences in the activities depending on the age of clusters, as well as confirmation of the existence of activities that are rather implemented by established than embryonic clusters. The study further confirmed the assumption of the existence of the life cycle in terms of implemented activities. Embryonic clusters are those which have existed less than 5 years. After this period, significant changes in the number of implemented activities and their preferences are observed.

\section{Acknowledgements}

The authors are thankful to the Technology Agency of the CR (TA CR), programme OMEGA, project No. TD010158 and to the Operational Programme Research and Development for 
Innovations co-funded by the European Regional Development Fund (ERDF) and national budget of Czech Republic within the framework of the Centre of Polymer Systems project (reg. No: CZ.1.05/2.1.00/03.0111), which provided financial support for this survey.

\section{References}

Andersson, T.; Schwaag-Serger, A.; Sörvik, J.; Hannson, E. 2004. The cluster policies whitebook. Sweden: IKED - International Organization for Knowledge Economy and Enterprise Development.

Audretsch, D. B.; Feldman, M. 1996. Innovative clusters and the industry life cycle, Review of Industrial Organization 11: 253-273. http://dx.doi.org/10.1007/BF00157670

Bergman, E. M. 2008. Cluster life-cycles: an emerging synthesis, in Karlsson, C. (Ed.). Handbook of research on cluster theory, handbooks of research on clusters series. Northampton, MA: Edward Elgar, 114-132. http://dx.doi.org/10.4337/9781848442849.00013

Blahova, M.; Knapkova, A. 2011. Effective strategic action: from formulation to implementation, in Juan, S. (Ed.). Economics, Business and Management. Manila: Int. Assoc. Computer \& Information Technology Press-IACSIT Press, 61-65.

Boschma, R. A.; Frenken, K. 2006. Why is economic geography not an evolutionary science? Towards an evolutionary economic geography, Journal of Economic Geography 6: 273-302. http://dx.doi.org/10.1093/jeg/lbi022

Brenner, T. 2004. Local industry cluster: existence, emergence and evolution. London and New York: Routledge. http://dx.doi.org/10.4324/9780203417249

Chandrapala, P.; Knapkova, A.; Kramna, E. 2010. Financial performance of selected firms in the Czech Republic, in Knowledge Management and Innovation: A Business Competitive Edge Perspective. Cairo, EGYPT: Int Business Information Management Assoc, Vols 1-3: 781-789.

Clusters Linked Over Europe. 2006. Cluster management guide - guidelines for the development and management of cluster initiatives [online]. Available from Internet: http://www.clusterforum.org/

Dalum, B.; Pederson, O. R.; Villumsen, G. 2005. Technological life-cycles; lessons from a cluster facing disruption, European Urban and Regional Studies 12(3): 229-246. http://dx.doi.org/10.1177/0969776405056594

Górzyński, M. 2006. System wsparcia gron w województwie podkarpackim - rekomendacje, in Górzyński, M. (Ed.). System wspierania gron przedsiębiorczości - publikacja podsumowująca. Rzeszów: IG WSIiZ, 95-119.

Grabher, G. 1993. The weakness of strong ties: the "lock-in" of regional development in the Ruhr area, in Grabher, G. (Ed.). The Embedded Firm: On the Socio-Economics of Industrial Networks. London: Routledge.

Hájek, O.; Novosák, J.; Hovorková, Z. 2011. Inovace a region: klastry a regionální inovační systém Zlínského kraje, E\&M Ekonomie a Management 14(2): 31-44.

Halbert, L. 2012. Collaborative and collective: reflexive co-ordination and the dynamics of open innovation in the digital industry clusters of the Paris region, Urban Studies 49(11): 2357-2376. http://dx.doi.org/10.1177/0042098011427186

Hassink, R. 2005. How to unlock regional economies from path dependency? From learning region to learning cluster, European Planning Studies 13(4): 521-535. http://dx.doi.org/10.1080/09654310500107134

Hope, A. 1968. A simplified Monte Carlo significance test procedure, Journal of the Royal Statistical Society. Series B (Methodological) 30(3): 582-598.

Innovating regions in Europe. IRE subgroup on regional clustering and networking as innovation drivers [online], Cluster Management (Learning module 5), [cited 15 March 2012]. Available from Internet: www.innovating-regions.org 
Klepper, S. 1996. Entry, exit, growth and innovation over the product life cycle, American Economic Review 86(3): 562-583.

Klepper, S. 1997. Industry life cycles, Industrial and Corporate Change 6(1): 145-181. http://dx.doi.org/10.1093/icc/6.1.145

Lechner, Ch.; Leyronas, Ch. 2012. The competitive advantage of cluster firms: the priority of regional network position over extra-regional networks - a study of a French high-tech cluster, Entrepreneurship and Regional Development 24(5-6): 457-473. http://dx.doi.org/10.1080/08985626.2011.617785

Lorenzen, M. 2005. Why do clusters change?, European Urban and Regional Studies 12: 203-208. http://dx.doi.org/10.1177/0969776405059046

Malakauskaite, A.; Navickas, V. 2010. Relation between the level of clusterization and tourism sector competitiveness, Inzinerine Ekonomika - Engineering Economics 21(1): 60-67.

Malakauskaite, A.; Navickas, V. 2011. Relation between a cluster's life cycle and competitiveness level, Economics and Management (Ekonomika ir vadyba) 16: 214-218.

Martin, R.; Sunley, P. 2006. Path dependence and regional economic evolution, Journal of Economic Geography 6: 395-437. http://dx.doi.org/10.1093/jeg/lbl012

Martin, R.; Sunley, P. 2011. Conceptualizing cluster evolution: beyond the life cycle model?, Regional Studies 45(10): 1299-1318. http://dx.doi.org/10.1080/00343404.2011.622263

Maskell, P.; Kebir, L. 2005. What qualifies as a cluster theory? DRUID Working Paper No 05-09, 2005. Department of Industrial Economics and Strategy, Copenhagen Business School.

Menzel, M. P.; Fornahl, D. 2009. Cluster life cycles - dimensions and rationales of cluster evolution, Industrial and Corporate Change 19(1): 205-238. http://dx.doi.org/10.1093/icc/dtp036

Molina-Morales, F. X.; Expósito-Langa, M. 2012. The impact of cluster connectedness on firm innovation: R\&D effort and outcomes in the textile industry, Entrepreneurship and Regional Development 24(7-8): 685-704. http://dx.doi.org/10.1080/08985626.2012.710260

Pavelková, D.; Jirčíková, E.; Knápková, A.; Skokan, K.; Škodáková, P.; Friedel, L. 2009. Klastry a jejich vliv na výkonnost firem. Praha: Grada.

Pavelková, D.; Jirčíková, E. 2008. Klastry jako nástroj zvýšení konkurenceschopnosti firem, E\&M Ekonomie a Management 11(3): 62-72.

Porter, M. E. 1990. The competitive advantage of nations. New York: Free Press. 855 p.

Pouder, R.; St. John, C. H. 1996. Hot spots and blind spots: geographical clusters of firms and innovation, Academy of Management Review 21(4): 1192-1225. http://dx.doi.org/10.5465/AMR.1996.9704071867

R Development Core Team. 2011. R: a language and environment for statistical computing [online]. R Foundation for Statistical Computing, Vienna, Austria. Available from Internet: http://www.R-project.org/

Saxenian, A. 1994. Regional advantage: culture and competition in Silicon Valley and Route 128. Cambridge: Harvard University Press.

Skokan, K. 2009. Regional clusters and the transformation of old industrial regions, in Bucek, M.; Capello, R.; Hudec, O.; Nijkamp, P. (Eds.). CERS 2009 - 3rd Central European Conference in Regional Science, International Conference Proceedings, Oct 07-09, 2009, 770-783.

Sonderegger, P.; Täube, F. 2010. Cluster life cycle and diaspora effects: evidence from the Indian IT cluster in Bangalore, Journal of International Management 16: 383-397. http://dx.doi.org/10.1016/j.intman.2010.09.008

Sölvell, Ö.; Lindqvist, G.; Ketels, C. 2003. The cluster initiative greenbook. Stockholm: Ivory Tower.

Sölvell, Ö. 2009. Clusters. Balancing evolutionary and constructive forces. Stockholm: Ivory Tower.

Staszewska, J. 2009. Wykorzystanie nowoczesnej koncepcji zarządzania przez sieć - przyczyny i skutki klasteringu, Przegląd Organizacji 1: 29-34.

Swann, G. M. P. 1998. Towards a model of clustering in high-technology industries, in Swann, G. M. P.; Prevezer, M.; Stout, D. (Eds.). The Dynamics of Industrial Clustering. Oxford: Oxford University Press, $52-76$. 
Tel Wal, A.; Boschma, R. 2011. Co-evolution of firms, industries and networks in space, Regional Studies 45(7): 919-933. http://dx.doi.org/10.1080/00343400802662658

Tichy, G. 1998. Clusters: less dispensable and more risky than ever, in Steiner, M. (Ed.). Clusters and Regional Specialization: On Geography, Technology and Networks. London: Pion, 226-237.

Utterback, J. M.; Abernathy, W. J. 1975. A dynamic model of process and product innovation, Omega 3(6): 639-656. http://dx.doi.org/10.1016/0305-0483(75)90068-7

Van Klink, A.; De Langen, P. 2001. Cycles in industrial clusters: the case of the shipbuilding industry in the northern Netherlands, Tjidschrift voor Economische en Sociale Geografie 92(4): 449-463. http://dx.doi.org/10.1111/1467-9663.00171

Wolter, K. 2003. Life cycle for clusters? The dynamics governing regional agglomerations. Conference presentation, "Clusters, Industrial Districts and Firms: The Challenge of Globalization", Modena, Italy.

Žižka, M. 2004. Metody identifikace klastrů, E\&M Ekonomie a Management 7(4): 32-46.

Žižka, M. 2008. Vliv klastrů na konkurenceschopnost podniků v České republice, Ekonomický časopisJournal of Economics 56(1): 39-52.

Žižka, M. 2012. Služby v kontextu podnikatelského prostředí České republiky, E\&M Ekonomie a Management 15(4): 97-107.

Eva JIRČÍKOVÁ is a graduate of Master's and Doctoral program at the Faculty of Management and Economics, Tomas Bata University in Zlín. Since October 2008, she has been a research staff member at the Centre of Applied Economic Research at FaME TBU in Zlín. Her research profile includes being author and co-author of more than 30 scientific articles, 1 monograph and 3 book chapters. During doctoral studies she focused her research activities primarily on the development of clusters and prepared a dissertation on "Identification of Factors Influencing the Cluster Development Process in the Czech Republic". Furthermore, she worked on the issues of measurement and management of companies' performance, managing business costs, and ensured teaching of Managerial Accounting. She also contributes to further projects oriented on the performance of organizations and business groups.

Drahomíra PAVELKOVÁ is working as a full Professor at Tomas Bata University in Zlin, Faculty of Management and Economics. She is a dean of the faculty. She presents on national and international conferences and published as author or co-author 6 monographs, 6 chapters in books and 31 articles in journals. She has managed 10 research projects. On different study visits she spent time abroad in Japan, USA, United Kingdom, France, Finland, Denmark, Sweden, Portugal and Belgium. Her areas of professional work and interest cover strategic management, clusters, corporate finance, performance management/measurement, corporate valuation and benchmarking.

Magdalena BIALIC-DAVENDRA has a Master of Arts (MA) in Economics from the University of Rzeszów, Poland, and has a Doctor of Philosophy (PhD) in Finance from Tomas Bata University in Zlín, Czech Republic. Currently, she holds a Postdoctoral research position at the Centre of Applied Economic Research, Faculty of Management and Economics, Tomas Bata University in Zlín. Her research profile includes being author and co-author of more than 20 scientific articles and 2 book chapters. She has been a leader of 4 and participant of 7 research projects. Her research interests cover: business clusters, finance, agricultural economics, operations research, and management science.

Lubor HOMOLKA is a graduate at the Faculty of Management and Economics, Tomas Bata University in Zlín, course Finance. Currently, he is a student of a doctoral study program at the aforementioned Faculty. He also teaches students, specifically in the subjects of Applied Statistics and Econometrics. He aims his research on the topic of financial performance measurement and applicability of statistical and machine learning methods in the field, contributes to research conducted within several research projects. 